\title{
Exploration of Bioactive Compounds Potency of Extract Namanereis sp. (Polychaeta: Annelida) as an Antibacterial Agent Against Escherichia coli and Staphylococcus aureus
}

\author{
Delianis Pringgenies ${ }^{1 *}$, Endah Sari ${ }^{1}$, Widianingsih Widianigsih ${ }^{1}$, Anuwat Nateewathana $^{2}$ \\ ${ }^{1}$ Department of Marine Sciences, Faculty of Fisheries and Marine Sciences, Diponegoro University \\ Jl. Prof. H. Soedarto, S.H., Tembalang, Semarang, Jawa Tengah, 50275 Indonesia \\ 2Departement of Marine and Coastal Resources, Bangkok, Thailand \\ Thung Song Hong, Lak Si, Bangkok 10210, Thailand \\ Email: delianispringgenies@lecturer.undip.ac.id
}

\begin{abstract}
Namanereis sp. belongs to class Polychaeta, a group of main benthic community in marine ecosystems. The purpose of this study to determine the potential of bioactive compounds from Namanereis sp. extract as an antibacterial agent and to determine its extract content through Gas Chromatography-Mass Spectrometry (GC-MS) analysis. Samples of Namaneries sp. were collected from Demak Waters, Central of Java. This research used experimental laboratory method. Samples were extracted with non-polar (N-Hexane), semi-polar (Ethyl acetate) and polar (Methanol) solutions. Different concentrations of extraction, i.e. 5, 10, 20, 40, 80, and $100 \mu$ g.disk-1. then were tested against pathogenic bacteria Escherichia coli and Staphylococcus aureus. The extract content analysis was obtained using the GC-MS method. The results showed that Namanereis sp. extract had a potential as an antibacterial agent. The highest inhibition zone was seen in the fraction with ethyl acetate solvent at a concentration of $100 \%$, namely $13 \pm 3.05 \mathrm{~mm}$ in E. coli and $14 \pm 3.04 \mathrm{~mm}$ in S. aureus, which then was analysed with GC-MS. Its results found 20 bioactive compounds in the extract. The five most dominant compounds determined by the highest peak were Dihydrojasmone (12.31\%), Hexanoic acid (11.49\%), Cholesterol (7.66\%), Cyclohexanol (7.53\%) and Isopropyl Palmitate (7.52\%). The research concluded that Namanereis sp. possessed antibacterial potency and contained several bioactive compounds.
\end{abstract}

Keywords: Polychaeta, Namanereis sp., antibacterial, bioactive compounds

\section{Introduction}

Secondary metabolites, also called natural products of organisms, are organic compounds that are not directly involved in the normal growth, development, or reproduction of an organism. These compounds function as individual defenses against predators, parasites, diseases, used in competition between species, and to facilitate the reproduction processes such as pigmentation, production and release of pheromones, and bioactive compounds (Pringgenies, 2019).

Bioactive compounds are found in immobile biota, such as invertebrate, and have a variety of potential applications in human life, such as a source of antioxidants, antibacterial agents, antiinflammatory substances and anticancer agents. (Pringgenies et al., 2018) Antibacterial agents are substances that can inhibit bacterial growth and can be used in the treatment of infections. Based on how it works, antibacterial agents can work as bacteriostatic and bactericidal (Ariyanti et al 2012).
Namanereis sp. are abundant along the coastal area of Demak, which is generally used as shrimp feed and fish bait. Namanereis sp is known to be nutritionally complete that contained protein, fat, carbohydrate, ash, fatty acids and amino acids, vitamins $A, B_{1}, B_{6}, B_{12}, E$, and $P, I_{2}, C a, M g, C$ minerals comparable to those found in fish. (Hadiyanto, 2013). Therefore, this study aims to determine the potential of Namanereis sp. as an antibacterial agent and determine the content of its bioactive compounds by GC-MS analysis.

\section{Materials and Methods}

\section{Sample collections}

Namanereis sp. samples were collected from waters of Demak, Central Java province, Indonesia. By using gloves, the samples were taken from its habitat, put into plastic bags, placed in a cool box filled with ice cubes, and were immediately transported to the laboratory. The samples were then rinsed with running water and soaked in aquabidest to ensure sterile samples. The sterile samples were 
sun-dried for 14 days. Dried samples were put in a $150^{\circ} \mathrm{C}$ oven for 120 mins for ideal dehydration.

\section{Extraction of Namanereis sp. samples}

Namanereis sp. extraction was initiated with a multilevel maceration process. 100 grams of samples were immersed in $350 \mathrm{ml}$ of $\mathrm{n}$-hexane solvent for $1 \mathrm{x}$ 24 hours. The results of the immersion were filtered while the residue was separated. Then the residue of $\mathrm{n}$-hexane immersed was re-immersed with ethyl acetate and methanol sequentially by the same process as with the n-hexane solvent. The extraction in this study uses the solid-liquid method with rotary evaporator for extraction (Doughari, 2012). After being filtered, the filtrate was evaporated with rotary vapor at $25^{\circ} \mathrm{C}$. The extract was transferred from the Erlenmeyer flask into the vial, then the sample with ethyl acetate filtrate and with methanol filtrate were alternately extracted using rotary evaporator (Burgess et al., 2003). The extract in vials was then stored in a refrigerator at $4^{\circ} \mathrm{C}$. (Vaikundavasagom et al., 2015).

\section{Positive and negative control tests}

The antibacterial activity test was conducted following the procedures of Balouiri et al. (2016), Pringgenies (2010) and Setyati and Subagiyo (2012). The positive control test was carried out using Amoxicillin, in which using bacteria at 80 mg.disk ${ }^{-1}$ concentration. This test aimed to determine and measure the diameter of inhibition zone formed by Amoxicillin antibiotics (Pringgenies, 2013). The form of inhibition zones was observed after 24 hours of incubation, then was measured. Negative control tests were carried out on test bacteria using $n$ hexane, ethyl acetate, and methanol as extract solvents. This test was carried out to determine the effect of the solvent used in the formation of inhibition zone (Hasanah et al., 2012).

\section{Antibacterial activity test on Namanereis sp.}

The antibacterial activity test of Namanereis sp. extract was carried out using the Kirby-Bauer disc diffusion method at different concentrations. Sterile NA media in a petri dish were allowed to stand until solidified. Pure extract at a concentration of $100 \%$ was then tested against pathogenic bacteria. The dissolved extract in ethyl acetate, in the form of a paste, was diluted with a DMSO solution to make an $80 \mu \mathrm{g} . \mu \mathrm{l}^{-1}$ stock solution at each concentration. The concentrations needed were 5, 10, 20, 40, 80, and $100 \mu$ g.disk ${ }^{-1}$ (Pringgenies, 2013). The paper disk was then placed on each test medium. A ten $\mu \mathrm{g} . \mu^{-1}$ diluted extract of each treatment was dropped using a micropipette on the paper disk. The test media were stored in an incubator at $37^{\circ} \mathrm{C}$ for $24 \mathrm{~h}$. After $24 \mathrm{~h}$, confirmation of the formation and measurement of the inhibition zone is done using a caliper. The inhibition zone formed was a clear zone formed around the paper disk. In this experiment, each treatment was triplicated.

\section{GC-MS test}

Namanereis sp. extract was put into the instrument, which was then separated into components and solutions. All compounds in the component were identified. Afterwards, quantitative analysis of each component was conducted. The amount of compound contained in the extract was indicated by the peak on the chromatogram, while the type of compound was interpreted from the spectrum data from each peak using the referential approach using the GC-MS database (Pringgenies, 2010).

Gas chromatography-mass spectrometry analysis was performed using the Shimadzu GC-MSTQ8030 engine with the following analysis conditions: linear velocity: $36.7 \mathrm{~cm} . \mathrm{sec}^{-1}$, purge flow: $3.0 \mathrm{~mL} . \mathrm{min}$ 1 , Helium carrier gas with injector temperature level at $345^{\circ} \mathrm{C}$, pressure $100.4 \mathrm{kPa}$, total flow $50 \mathrm{~mL}$. min 1, column flow $0.90 \mathrm{~mL} \cdot \mathrm{min}^{-1}$, purge flow $3 \mathrm{~mL} \cdot \mathrm{min}^{-1}$, split ratio -1 and programmed column temperature of $200^{\circ} \mathrm{C}$ (maintained for $1 \mathrm{~min}$ ) to $340^{\circ} \mathrm{C}$ (maintained for $10 \mathrm{mins}$ ) at a rate of temperature rise of $14^{\circ} \mathrm{C} \cdot \mathrm{min}^{-1}$, ion source temperature of $200^{\circ} \mathrm{C}$ and interface temperature of $200^{\circ} \mathrm{C}$.

\section{Results and Discussion}

\section{Extraction of Namanereis sp. samples}

The resulting extract texture was paste-like. The extraction results also indicated that the methanol solvent produced more extracts $(6.8 \mathrm{mg})$, compared to the lowest yield obtained from the ethyl acetate solvent (1.25 mg) (Table 1.).

\section{Positive and negative control tests}

A positive control test was carried out against the amoxicillin antibiotic, to determine the activity of the test bacteria. Amoxicillin was confirmed to form a zone of inhibition against test bacteria. The highest activity of Amoxicillin was found in S. aureus, while the lowest was found in E. coli (Table 2.). Amoxicillin is a broad-spectrum, $\beta$-lactamase antibiotic and is often used to treat various infectious diseases caused by Gram- positive and Gram-negative bacteria such as ear infections, pneumonia, streptococcal pharyngitis, skin, urinary tract, Salmonella, Chlamydia infections and Lyme disease. The indication of the formation of inhibitory zones can be observed from 
Table 1. Extraction of Namanereis sp.

\begin{tabular}{ccll}
\hline Solvent & Extract weight $(\mathrm{mg})$ & Shape & Color \\
\hline N-Hexane & 3.09 & paste & Blackish brown \\
Ethyl acetate & 1.25 & paste & Blackish brown \\
Methanol & 6.8 & paste & Blackish brown \\
\hline
\end{tabular}

the clear zone and was used as a reference for determining the level of bacterial resistance to antibiotics used, where the diameter of the clear zone formed was inversely proportional to the growth rate of pathogenic bacterial colonies. There are three levels of bacterial resistance, namely sensitive, intermediate and resistant. A bacterial species was sensitive to an antibacterial agent if a clear zone was formed and resistant if no clear zone is formed from the test results. While the level of intermediate resistance is characterized by clear zones with small diameters (Jawetz et al., 2001).

Inadequate concentration of antibiotics will eventually enhance the resistance of $S$. aureus and E. coli. The concentration used in this study was 80 $\mu g$. disk $^{-1}$, because at that concentration Amoxicillin was able to penetrate the outer membrane of each test bacterium. Inhibition zones of $32 \pm 1 \mathrm{~mm}$ in $\mathrm{S}$. aureus and $22.33 \pm 15.37 \mathrm{~mm}$ in $E$. coli (Table 2.) reinforce the findings of previous studies, which stated that the greater the concentration of the test, the greater the inhibition zone formed (Azis and Cahyadi, 2020).

The results of negative control tests with solvents showed no significant antibacterial activity. The three solvents produced no inhibition zone. Therefore, it can be concluded that the solvent does not affect the activity of the test bacteria (Table 3 .). Negative control tests were also carried out to determine the level of contamination in bacterial culture media. This test was carried out in accordance

Table. 2. Diameter of Inhibition Zone on test bacteria by Amoxicillin

\begin{tabular}{lc}
\hline \multicolumn{1}{c}{ Test Bacteria } & Inhibition Zone $(\mathrm{mm})$ \\
\hline Escherichia coli & $22.33 \pm 15.37$ \\
Staphylococcus aureus & $32 \pm 1$
\end{tabular}

Table 3. Inhibition Zone of Extracts with Various Solvents on Test Bacteria

\begin{tabular}{lccc}
\hline \multirow{2}{*}{ Test Bacteria } & \multicolumn{3}{c}{$\begin{array}{c}\text { Diameter of Inhibition Zone } \\
(\mathrm{mm})\end{array}$} \\
\cline { 2 - 4 } & $\begin{array}{c}\mathrm{N}- \\
\text { Hexane }\end{array}$ & $\begin{array}{c}\text { Ethyl } \\
\text { acetate }\end{array}$ & Methanol \\
\hline $\begin{array}{l}\text { Escherichia coli } \\
\begin{array}{l}\text { Staphylococcus } \\
\text { aureus }\end{array}\end{array}$ & 0 & 0 & 0 \\
& 0 & 0 & 0 \\
\hline
\end{tabular}

with the solvent used in the extraction process, namely n-hexane, ethyl acetate and methanol. In the negative control test, no inhibition zone formation was found. These results can explain that the antibacterial activity of each extract was not influenced by the solvent used, but rather by the active compound contained in the extract of Namanereis sp. (Salwan et al., 2020).

\section{Antibacterial activity test on Namanereis sp. against test bacteria}

The qualitative test of antibacterial activity of Namanereis sp. extract was carried out at concentrations of $5,10,20,40,80$, and $100 \mu$ g.disk 1 . The extracts with six different concentrations were tested against $E$. coli and $S$. aureus. A qualitative test with a $100 \%$ extract concentration was conducted with an observation period of $1 \times 24 \mathrm{~h}$. The results of this test indicated that the fraction with ethyl acetate solvent gave the largest inhibition zone compared to the fraction with $\mathrm{n}$-hexane and methanol solvents (Table 4.).

S. aureus and E. coli were used as test bacteria based on the representation of the two bacteria as gram-positive bacteria (Methicillinresistant S. aureus) and gram-negative bacteria ( $E$. coli). The potential of antibacterial compounds in Namanereis sp. extract in this research was determined by antibacterial activity test against the selected test bacteria. The inhibition zone formed around the paper disk indicated its antibacterial activity. Observations revealed that different fractions showed different antibacterial activities at the same extract concentration, at $100 \%$. The methanol extract produced no inhibitory zone, which meant that the test bacteria were resistant to the fraction of Namanereis sp. extract with methanol solvent. This finding indicated a different result than previous studies on Polychaeta, where the best results obtained came from the methanol fraction (Elayaraja et al., 2010) in which the inhibition zones formed was $7 \mathrm{~mm}$ in E. coli and $8 \mathrm{~mm}$ in S. aureus. Bacteria were not resistant to methanol fraction extracts. One of the factors that might affect the difference in results was the difference in sample species, where previous studies used Perinereis cultrifera while this study using Namanereis sp. Differences in treatment of the sample can also affect the results; in previous studies 
used fresh samples while in this study dry samples was tested.

The n-hexane fraction indicated the antibacterial activity with inhibition zones of $2 \pm 3.46$ $\mathrm{mm}$ in S. aureus and $6 \pm 6 \mathrm{~mm}$ in $E$. coli. The ethyl acetate fraction produced the most significant inhibition zone with $13 \pm 3.05 \mathrm{~mm}$ in $E$. coli and $14 \pm 3.04 \mathrm{~mm}$ in $\mathrm{S}$. aureus. These findings indicated that the inhibition of the ethyl acetate fraction was better when compared to the n-hexane and methanol fractions.

The extract with ethyl acetate solvent was selected to be used in further testing at different concentrations. The smallest concentration of the extract $\left(5 \mu \mathrm{g}\right.$. disk $\left.^{-1}\right)$ resulted in the absence of inhibition zone on all pathogenic bacteria (Table 5). Antibacterial tests were carried out to determine the efficacy of administered antibacterial substances in different concentrations. This test was only carried out on the extract of Namanereis sp. from the ethyl acetate fraction. The extract was diluted with DMSO solution, since it is able to dissolve polar and nonpolar compounds, as well as to act as a negative control. The use of DMSO has relatively no effect on cell proliferation, so it will not interfere $h$ the results of observation and testing of antibacterial activity with the agar diffusion method (Tjernberg et al., 2006).

Tabel 5 showed that the results of $5 \mu$ g.disk ${ }^{-1}$ dilution test showed that both test bacteria were no resistant to the antibacterial compounds contained in the extract of Namanereis sp. At a concentration of $80 \mu$ g.disk ${ }^{-1}$, gave the highest inhibitory zones formed, i.e. $7 \pm 0.86 \mathrm{~mm}$ and $7.33 \pm 6.42$ for $E$. coli and $S$. aureus respectively. The resulting reaction of the test bacteria to the extract of Namanereis sp. was caused by differences in the structure of cell wall of test bacteria. S. aureus is a gram-positive bacterium, which has a relatively simpler cell wall structure compared to that of gram-negative bacteria (Ariyanti et al.,2012). E. coli is a gram-negative bacterium that has more complex, three-layered cell wall structure with an outer layer of lipoprotein, a thick middle layer of peptidoglycan and an inner layer of lipopolysaccharide. The simpler wall structure of the gram-positive bacterial cell wall makes it easy for antibacterial compounds to penetrate the cell wall and find targets to work. Conversely, complex cell walls inhibit bioactive compounds to penetrate bacterial cell membranes, so that $E$. coli is less sensitive to these bioactive compounds (Tjernberg et al., 2006). This is shown by the difference in diameter of inhibition zones of $S$. aureus and $E$. coli

The concentration of the extract used gave significantly impact to the levels of antibacterial activity. The less concentration administered, the smaller diameter of inhibition zone formed. The antibiotics compound in Namanereis sp. extract worked in a similar fashion to that in Amoxicillin antibiotics. Inadequate concentration used in the treatment may result in the absence of inhibition zone (Rahmawati et al., 2016) due to the fact that antibacterial compound will only be able to penetrate the outer membrane of pathogenic species cell walls at high concentration.

\section{GC-MS test}

GC-MS analysis was performed on active isolates with ethyl acetate as a fraction of the best antibacterial activity. The compounds of the extract were determined using Gas Chromatography. GC-MS analysis obtained 20 peak compounds with different percentages and retention times (Table 6.). GC-MS analysis on the sample ethyl acetate fraction showed that, of the 20 main peaks that were detected, there were only 5 with high and dominant main compounds, namely Dihydrojasmone 12.31\%, Hexanoic acid 11.49\%, Cholesterol 7.66\%, Cyclohexanol 7.53\% and Isopropyl Palmitate 7.52\%. GC-MS results in the sample fraction with ethyl acetate solvent showed that 20 major peaks were detected, but there were only the more dominant five compounds detected, i.e. Dihydrojasmone $12.31 \%$, Hexanoic acid 11.49\%, Cholesterol 7.66\%, Cyclohexanol 7.53\% and Isopropyl Palmitate 7.52\%.

Namanereis sp. has neuropodia with two bundles of setae. The spinigganas superior part and the falcigerous inferior portion of a skeleton collaborate in turning the CIS-jasmone into a dihydrojasmone precursor (Zealand, 1999). This process was thought to be a contributor to the high peak of Dihydrojasmone in the GC-MS test. In the last 3 decades, the demand for Dihydrojasmone in the perfume industry has been very high, making the extract of Namanereis sp. a viable alternative for raw material in the perfume industry. Dihydrojasmone can also be used as a test target in the development of cyclopentenone synthesis (Ho, 1972).

Hexanoic acid and cholesterol are important compounds for the human body in the process of forming brain cells and hormones. Adequate intake of hexanoic acid can prevent dementia while cholesterol can form immune system hormones (Cheon et al., 2014). These benefits are believed to be a drivingfactor of Namanereis sp. consumption in the coastal community of Jepara in traditional medicine. The efficacy of hexanoid acid in accelerating gonad maturation made Namanereis sp. widely used natural shrimp feed by local aqua farmers (Hadiyanto, 2013). 
ILMU KELAUTAN: Indonesian Journal of Marine Sciences September 2021 Vol 26(3):182-188

Table 4. Test Results of $100 \%$ Extract with Various Solvents

\begin{tabular}{cccc}
\hline \multirow{2}{*}{ Test Bacteria } & \multicolumn{3}{c}{ Diameter of Inhibition Zone $(\mathrm{mm})$} \\
\cline { 2 - 4 } & N-Hexane & Ethyl acetate & Methanol \\
\hline Escherichia coli & $6 \pm 6$ & $13 \pm 3.05$ & 0 \\
Staphylococcus aureus & $2 \pm 3.46$ & $14 \pm 3.04$ & 0 \\
\hline
\end{tabular}

Table 5. Qualitative Test Results of Namanereis sp. Extract with Ethyl Acetate against Test Bacteria on Various Concentrations

\begin{tabular}{ccccccc}
\hline \multirow{2}{*}{ Test Bacteria } & \multicolumn{5}{c}{ Diameter of Inhibition Zone $(\mathrm{mm})$} \\
\cline { 2 - 7 } & $100 \%$ & $80 \mu \mathrm{g}$. disk $^{-1}$ & $40 \mu$ g.disk $^{-1}$ & $20 \mu \mathrm{g}$. disk $^{-1}$ & $10 \mu \mathrm{g}$. disk $^{-1}$ & $5 \mu \mathrm{g}$. disk $^{-1}$ \\
\hline E. coli & $13.33 \pm 3.04$ & $7 \pm 0.86$ & $6.66 \pm 1.04$ & $5.16 \pm 0.28$ & $3.73 \pm 3.23$ & 0 \\
S. aureus & $14 \pm 3.04$ & $7.33 \pm 6.42$ & $1.33 \pm 2.03$ & $1.66 \pm 2.88$ & $1.5 \pm 2.59$ & 0 \\
\hline
\end{tabular}

Table 6. GC-MS Analysis Results

\begin{tabular}{|c|c|c|c|c|}
\hline Peak & $\begin{array}{l}\text { Retention } \\
\text { Time }\end{array}$ & Area & $\begin{array}{l}\text { Concentration } \\
(\%)\end{array}$ & Compound \\
\hline 1 & 3,140 & 925451565 & 7.52 & Isopropyl Palmitate \\
\hline 2 & 3,201 & 1413084787 & 11.49 & $\begin{array}{l}\text { Hexanoic acid, 6-(acetylamino)-3-[[3,6-bis(acetylamino)-1-oxohexyl] } \\
\text { amino]-, methyl ester }\end{array}$ \\
\hline 3 & 3,265 & 766169732 & 6.3 & Pyridin, 2-methoxy-5-nitro \\
\hline 4 & 3,644 & 134778365 & 1.10 & Benzene, 1-(chloromethyl)-2-nitro- \\
\hline 5 & 4,055 & 1514210322 & 12.31 & Dihydrojasmone \\
\hline 6 & 4,191 & 673168973 & 5.47 & Hexadecanoic acid, 14-methyl-, methyl ester \\
\hline 7 & 4,314 & 899788762 & 7.32 & Acetamide,2-[2 (hexyloxy)ethoxy]-N,N-dipropyl \\
\hline 8 & 4,395 & 299034246 & 2.43 & $\begin{array}{l}\text { Cyclohexene, 4-ethenyl-4-methyl-3-(1-methylethenyl)-1-(1-methylethyl), } \\
\text { (3R-trans)- }\end{array}$ \\
\hline 9 & 4,610 & 465710426 & 3.79 & 2-Naphthalenol, 1-nitro- \\
\hline 10 & 4,798 & 803944875 & 6.54 & Oxirane, hexadecyl \\
\hline 11 & 5,394 & 424634820 & 3.45 & 1,2-Ethanediamine,N-(2-aminoethyl)-N'-[2-[(2-aminoethyl)amino]ethyl]- \\
\hline 12 & 5,820 & 925649776 & 7.53 & $\begin{array}{l}\text { Cyclohexanol, 5-methyl-2-(1-methylethenyl)-, [1R-(1.alpha.,2.beta., } \\
\text { 5.alpha.)]- }\end{array}$ \\
\hline 13 & 5,899 & 510604149 & 4.15 & Oxirane, hexadecyl- \\
\hline 14 & 6,220 & 502474677 & 4.08 & Di-n-octyl phthalate \\
\hline 15 & 6,290 & 154520178 & 1.26 & Octadecanoic acid, 3-hydroxy-, methyl ester \\
\hline 16 & 6,345 & 118390854 & 0.96 & 9-Octadecenamide, (Z)- \\
\hline 17 & 6,504 & 168981701 & 1.37 & Dodecan-1-yl acetate \\
\hline 18 & 6,785 & 530293525 & 4.31 & 1,3-Benzenedimethanol, 2-hydroxy-5-methyl- \\
\hline 19 & 9,209 & 941923357 & 7.66 & Cholesterol \\
\hline 20 & 9,765 & 127687644 & 1.04 & Cyclohexanol, 2-methyl-5-(1-methylethenyl)-, (1.alpha.,2.alpha.,5.beta.)- \\
\hline
\end{tabular}

Cyclohexanol is the main compound in nylon production. This compound can be used as an industrial-grade solvent and plasticizer base material. Cyclohexanol also has wide range of applications, among them are in disinfectants, seasonings, pesticides, disinfectants, wood preservatives and skin softeners (Pei et al., 2015). Isopropyl palmitate is most often found in skincare or beauty products. Isopropyl palmitate (IPP) ester is a dry, soft, non-oily emollient. This compound is used as an excellent solvent for mineral oil, silicon and lanolin IPP, and is widely used in cosmetics and topical drug preparations which are well-absorbed through skin contact (Liu et al., 2015). The content of isopropyl palmitate in the extract of Namanereis sp. is thought to be a factor that gave a benefit results of the tests on Methicillin-resistant S. aureus (MRSA). S. aureus is a pathogenic species whose infestations in humans and animals cause diseases ranging from mild skin infections, such as folliculitis and furunculosis, to lifethreatening infections such as sepsis, pyogenic, deep abscesses, to fatal septicemia (Nursidika et al., 2014). Finally, the Namanereis sp. extract can be developed into a medicine for treating skin infections caused by S. aureus.

\section{Conclusion}

Namanereis sp. extract with ethyl acetate fraction has potential antibacterial compounds. This 
finding is evidenced by the inhibition zone of $13 \pm 3.05$ $\mathrm{mm}$ against pathogenic bacteria $E$. coli and $14 \pm 3.04$ $\mathrm{mm}$ to $\mathrm{S}$. aureus). GC-MS analysis indicated that the extract of Namanereis sp. with ethyl fraction had 20 bioactive compounds and five were dominant compounds, namely Dihydrojasmone $12.31 \%$, Hexanoic acid 11.49\%, Cholesterol 7.66\%, Cyclohexanol 7.53\% and Isopropyl Palmitate $7.52 \%$.

\section{Acknowledgement}

We would like to thank the technicians in Laboratory Biotechnology, Dept. of Marine Sciences, Faculty of Fisheries and Marine Sciences, University of Diponegoro.

\section{References}

Azis, A. \& Cahyadi, J. 2020. Benefits of Tiwai Onion (Eleutherine americana) Extract as Phytopharmaceutical Plant to Inhibit the Growth of Vibrio harveyi Through in-Vitro and in-Vivo. J. IImiah Perikanan dan Kelautan. 12(1): 105-112. doi: 10.20473/jipk.v12i1.128 26

Ariyanti, N.K., Darmayasa, I.B.G. \& Sudirga, S.K. 2012. Daya hambat ekstrak kulit daun lidah buaya (Aloe barbadensis Miller) terhadap pertumbuhan bakteri Staphylococcus aureus ATCC 25923 dan Escherichia coli ATCC 25922. J. Biologi. 16(1):1-4.

Burgess, J.G., Boyd, K.G., Amstrong, E., Jiang, Z., Yan, L., Berffren, M., May, U., Psacane, T., Granmo, A. \& Adams, D.R. 2003. Development of a Marine natural Product-based Antifouling Paint. Biofouling, 19: 197-205

Balouiri. M., Sadiki, M. \& Ibnsouda, S.K. 2016. Methods for in vitro evaluating antimicrobial activity: A review. J. Pharm. Anal. 6(2): 71-79. doi: 10.1016/j.jpha.2015.11.005.

Cheon, J.Y., Kim, J.H., Kim, J.H., Goddeti, K.C., Park, J.Y. and Joo, S.H., 2014. Intrinsic relationship between enhanced oxygen reduction reaction activity and nanoscale work function of doped carbons. J. Am. Chem. Soc., 136(25): 8875-8878.

Doughari, J.H. 2012. Phytochemicals: Extraction methods, basic structures and mode of action as potential chemotherapeutic agents. In: Rao, V. (Ed.). Phytochemical - A Global Perspective of Their Role in Nutrition and Health, INTECH Open Access Publisher. doi: 10.5772/26052

Elayaraja, S., Murugesan, P., Vijayalakshmi, S. \& Balasubramanian, T. 2010. Antibacterial and antifungal activities of polychaete Perinereis cultrifera. Indian J. Mar. Sci., 39(2):257-261

Hadiyanto. 2013. Nilai Ekonomis Cacing Laut (Annelida: Polychaeta). Oseana. 28(3): 23-31

Hasanah, N.F., Delianis, P. \& Wulandari, S.Y. 2012. Karakterisasi Metabolit Sekunder Bakteri Simbion Gastropoda Conus miles dengan Metode GC-MS Sebagai Antibakteri MDR (Multi Drug Resisiten). J. Mar. Res., 1(2): 197-202

Ho, C. 1972. Synthesis of cis-Jasmone and Dihydrojasmone. Can. J. Chem., 50(16): $2718-$ 2721.

Jawetz, E., Melnick, J.L. \& Adelberg, E.A. 2001. Mikrobiologi Kedokteran. Nani W, penerjemah. Jakarta (ID): Salemba Medika. Translate from Medical Microbiology. 196-198p.

Liu, M., Wen, J. \& Sharma, M., 2020. Solid lipid nanoparticles for topical drug delivery: Mechanisms, dosage form perspectives, and translational status. Curr. Pharm. Des., 26(27): 3203-3217.

Nursidika, P., Saptarini, O. \& Rafiqua, N. 2014. Aktivitas Antimikroba Fraksi Ekstrak Etanol Buah Pinang (Areca catechu L.) pada Bakteri Methicillin Resistant Staphylococcus aureus. Majalah Kedokteran Bandung, 46(2): 94-99.

Pringgenies, D. 2010. Karakteristik Senyawa Bioaktif Bakteri Simbion Molusca Dengan GC-MS. J. IImu dan Teknologi Kelautan Tropis, 2(2):34-40. doi: 10.28930/jitkt.v2i2.7850

Pringgenies, D. 2013. Antibacterial Activity of Sea Cucumbers Harvested from Karimunjawa. Squalen Bulletin of Marine \& Fisheries Postharvest \& Biotechnology, 8(2): 87-94

Pringgenies, D. 2019. Bioprospeksi bahan hayati laut untuk pengembangan industri Farmasi di Indonesia. Undip Press Semarang. ISBN: 978979-097-637-5.

Pringgenies, D., Rudiyanti, S. \& Yudiati, E. 2018. Exploration of Sea Cucumbers Stichopus hermanii from Karimunjawa Islands as Production of Marine Biological Resources. 3rd International Conference on Tropical and Coastal Region Eco Development 2017. IOP Conf. Series: Earth Environ. Sci., 116: 012039 doi: 10.1088/1755-1315/116/1/012039

Pei, Y., Wang, Q., Gong, X., Lei, F. \& Shen, B. 2015. Distribution of cyclohexanol and cyclohexanone between water and cyclohexane. Fluid Phase 
Equilibria. 394: 129-139. doi: 10.1016/j.fluid. 2015.02.029

Rahmawati, U., Agustini T.W. \& Romadhon. 2016. Kajian Aktivitas Antibakteri Ekstrak Lamun (Thalassia hemprichii) Terhadap Bakteri Staphylococcus aureus dan Escherichia coli. In: Prosiding Seminar Nasional Tahunan Ke V 2015 Hasil Hasil Penelitian Perikanan dan Kelautan. Fakultas Perikanan dan IImu Kelautan UNDIP, pp. 466-473.

Salwan, R. \& Sharma, V. 2020. Bioactive compounds of Streptomyces: Biosynthesis to applications. In: Atta-ur-Rahman (Ed.) Studies in Natural Products Chemistry (Vol. 64; $1^{\text {st }}$ ed.). Elsevier. doi: 10.1016/B978-0-12-817903-1.000 15-2.
Setyati, W.A. \& Subagiyo. 2012. Isolasi dan Seleksi Bakteri Penghasil Enzim Ekstraseluler (Proteolitik, amilolitik, lipolitik dan selulolitik) yang Berasal dari Sedimen Kawasan Mangrove. IImu Kelautan: Indonesian Journal of Marine Sciences, 17(3): 164-168

Tjernbergh, A., Natalia, M., William, J.G., Griffths., \& Dan. H. 2006. DMSO-Related Effects in Protein Characterization. J. Biomol. Screen., 11(2): 131-137.

Vaikundavasago, C., Shankar, S., Satheesh, S., Viju, N., Mary, S., \& Punitha, J. 2015. Antibacterial and biofilm inhibitory activities of bacteria associated with Polychaetas. J. Coast. Life Med., 3(6): 495-502. doi: 10.12980/jclm.3.2015jcl m-2015-0012 